Наталія Чендей Кандидат філологічних наук, доиент кафедри англійської філології ДВНЗ «УжНУ», orcid.org/0000-0003-4065-5119

Ужсгород, Україна,+380502764322, nataliia.chendei@uzhnu.edu.иа

Дарина Станко Кандидат філологічних наук, дочент кафедри англійської філології ДВНЗ «УжНУ», orcid.org/0000-0003-7858-8663 Ужггород, Україна, +380506568746, dashastanko@gmail.com

\title{
Інтертекстуальність як текстова категорія та особливості інтертекстуальних зв'язків в англійській літературній казці
}

Анотація. У статті йдеться про поняття «інтертекстуальність» як особливу текстову категорію, щзо виконує ряд важливих функиій, зокрема смислоутворюючу та інтегруючу. Окрему увагу автори зосереджують на вивченні прагматичного аспекту інтертекстуальністі, щьо виступає як специфічна стратегія відповідності з іншими (попередніми) текстами, а також як спосіб, за допомогою якого один текст актуалізує у своєму 
внутрішньому просторі інший, виражаючи задум автора. Відповідно інтертекстуальність охоплюе увесь спектр можливих віртуальних відношень між текстами і їхніми частинами. Таким чином, текст у процесі інтертекстуалізації постійно трансформується, створює і переосмислює, залишаючись відкритим для нових змін.

Ключові слова: інтертекстуальність, текст, поліфонія, когнітивна модель, літературна казка.

Abstract. The article deals with the notion of "intertexuality" as a singular text category that performs a range of important functions, in particular integrating and content-forming. Much attention has been paid to a pragmatic aspect of intertexuality that is viewed as a specific correlating strategy with some other (earlier created) texts, as well as a mode of actualizing a different text or its parts in an inner space of a new text, expressing an author's purport. Texts of literary fairytales belong to the so called dynamic models of text organization ( $R$. Green). Dynamic models target at the receiver, being based on the associations and text openness. Architextuality or text correlation to genre is vital, as any fairytale roots from a national folklore heritage. The impact of a folklore tale can be traced on the level of literary tale composition, its constituent elements and their correlation.

Keywords: intertexuality, text, polyphony, cognitive model, literary fairytale.

Вступ. Герменевтика займається інтерпретацією та розумінням текстів. Незважаючи на той факт, що проблема аналізу художнього тексту давно знаходиться у центрі уваги філологів, цілісне розуміння про творчий процес, беручи до уваги досягнення у галузі когнітивної лінгвістики, психолінгвістики, лінгвокультурології, психології особистості, літературознавства, у науці й досі не сформовано.

У лінгвістиці поняття тексту має широке тлумачення, оскільки воно охоплює i спосіб відображення дійсності, побудований за допомогою елементів системи мови, і основну одиницю комунікації, спосіб збереження і передачі інформації, і форму існування культури, і відображення психічного стану індивіда тощо.

Однією 3 фундаментальних категорій герменевтики як науки тлумачення текстів $є$ інтертекстуальність. Інтертекстуальність як текстова категорія у суто лінгвістичному смислі виражає особливий спосіб побудови смислу тексту. Слід зауважити, що термін «інтертекстуальність» у широкому значенні вживається для позначення явищ текстової діалогічності. Поруч 3 цим терміном, вживаються такі суміжні поняття, як: поліфонія, полілогізм, транспозиція, діалогічність, бівокалічність, транстекстуальність, інтерсемантичність. Проте «інтертекстуальність» користується широким попитом. Згадані раніше поняття не $\epsilon$ взаємозамінними, оскільки відображають різні теоретичні погляди розуміння діалогу текстів. Не існує 
однозначності і в трактуванні інтертекстуальності, що визначає актуальність цієї наукової розвідки.

Методологія та методи дослідження. Методологічну основу дослідження побудовано на теоретичних працях I. В. Арнольд, М. М. Бахтіна, В. Я. Проппа, Ю. Крістєвої та інших. Основними методами дослідження є структурно-семіотичний метод, елементи когнітивного аналізу (прототипний метод), а також методи лінгвостилістичного та літературознавчого аналізу.

Виклад основного матеріалу дослідження. І. Р. Гальперін дає таке визначення тексту: «Текст - це твір мовотворчого процесу, що має завершеність, яка об'єктивується у формі письмового документа; твір, що складається з назви (заголовка) і ряду основних одиниць, об'єднаних різними типами лексичного, граматичного, логічного, стилістичного зв'язку, що має визначену ціленаправленість і прагматичну установку» [4, с. 18].

Текст характеризується певними загальними ознаками. І. Р. Гальперін виокремлює такі ознаки тексту, як: інформативність, когезія, членування тексту, континуум (категорії художнього простору і часу), автосемантичність відрізків тексту, ретроспекція і проспекція в тексті, модальність тексту (суб’єктивну і обєктивну), інтеграція і завершеність тексту.

Учений розмежовує змістовно-фактуальну (повідомлення про факти, події, процеси, що відбулися, відбуваються і будуть відбуватися в навколишньому світі, реальному чи уявному), змістовно-концептуальну (індивідуально-авторське розуміння відношень між явищами, розуміння їхнього причинно-наслідкового зв'язку, їхня значимість у соціальному, економічному, культурному житті народу, включно 3 стосунками між індивідуумами, їх складної психологічної й естетико-пізнавальної взаємодії) і змістовно-підтекстну (прихована інформація, яка розуміється завдяки здатності одиниць мови породжувати асоціативні і конотативні значення, а також завдяки здатності речень всередині СФО нарощувати смисли) інформації тексту [4, с. 27].

Художній текст $є$ певним чином організованою засобами мови системою. Водночас це результат текстоутворюючої діяльності автора i декодування зі сторони читача. Будучи втіленням концептуальної картини світу конкретної мовної особистості, художній текст допомагає глибше розкрити природу індивідуально-особистісного фактору в мові; нарешті, художній текст - це, беззаперечно, продукт культурної комунікації. Головною ознакою художнього способу пізнання дійсності є його естетичне начало.

Мислення письменника суб’єктивне, «вторинна дійсність», яку він зображує, $\epsilon$ вигадкою, i читач це розуміє. Тому художнє пізнання характеризується подвійною суб'єктивністю. Суб’єктивний момент слугує автору як засіб художнього відкриття і втіленням життєвої об'єктивності. 
Художне мислення принципово побудоване на образній аналогії. На думку багатьох дослідників, у власне створенні художнього твору письменник іде метафоричним шляхом, шляхом переносу: на основі життєвих спостережень він будує, у значній мірі в підсвідомості, загальну понятійну модель того чи іншого життєвого комплексу, але втілює їі у нову конкретність - конкретність образної вигадки.

Метафоричність художнього мислення визначає змістову двоплановість художнього мовлення. 3 іншого боку, i сприйняття художнього образу вирізняється двома планами: зовнішній образ виявляється причиною розвитку емоційного відзиву, який породжує асоціативні зв'язки й будує у мовній свідомості внутрішній образ.

Вивчення особливостей семантики мовних одиниць i їхнього природного контекстуального оточення необхідне для аналізу семантикостилістичних особливостей будь-якого тексту. На думку Л. А. Новікова, контекстуальний смисл слова в художньому творі $\epsilon$ надважливим для розуміння всього тексту, адже слово «наділене особливою естетичною функцією, часто неповторне у своєму вживанню, індивідуальне. Саме тому розкриття контекстуального значення, естетичної значимості мовних одиниць - одне з важливих і водночас складних завдань» [7, с. 22]. За умови багатозначності мовних форм контекст $\epsilon$ вирішальним фактором встановлення справжнього змісту відповідних мовних форм.

Лінгвосеміотичне визначення тексту передбачає той факт, що дослідник має справу 3 «окремим, закритим в собі й цілісним, нерозчленованим значенням й функцією семіотичним утворенням» $[6$, с. 188]. «Різноманістність структурних зв'язків всередині тексту різко знижує самостійність окремих його одиниць і підвищує коефіцієнт зв'язності тексту. Текст прагне перетворитися в окреме «велике слово» із спільним єдиним значенням. $<\ldots>>$ Художній текст ніби переноситься у семіотичний простір 3 великою кількістю вимірів» [6, с. 188].

Визначення інтертекстуальності зводяться до іiі розуміння як до «наявності одного чи кількох передтекстів в іншому і як відношення, що виникають між текстом і його передтекстом (-ами)» [9, с. 175].

У семіотичному плані це означає відношення між різними мовними знаковими системами, що референтно відповідають одна одній. У прагматичному плані інтертекстуальність виступає як специфічна стратегія відповідності з іншими текстами, як той спосіб, за допомогою якого один текст актуалізує у своєму внутрішньому просторі інший, виражаючи задум автора. Відповідно, інтертекстуальність охоплює увесь спектр можливих віртуальних відношень між текстами і їхніми частинами.

Ідеєю інтертекстуальності займаються семіотики, вона має глибокі традиції осмислення у філософії, літературознавстві й лінгвістиці, наразі вивчається на основі комунікативно-когнітивних уявлень про текст. Як вид текстової взаємодії, обмежений цитатами, алюзіями i плагіатом, 
інтертекстуальність протиставляють паратекстуальності - відношенню тексту до заголовка, епіграфа і післямови; метатекстуальності коментування або критичне посилання на інший текст; гіпертекстуальності висміюванні або пародіюванні одного тексту іншим; i нарешті архітекстуальності - жанровому зв' язку текстів.

Наукове обгрунтування ідея інтертекстуальності одержала у працях М. М. Бахтіна, у яких були сформульовані поняття поліфонії та діалогічності. Учений стверджував, що автор завжди веде діалог з сучасною та минулою літературою, і текст відображає всі інші тексти певної смислової форми. Інакше кажучи, автор художнього твору має справу не тільки 3 дійсністю загалом, але вже 3 оціненою й оформленою дійсністю. Принагідно зауважимо, що сама ідея розробки інтертекстуальності означала визнання смислової відкритості тексту, а значить закономірно супроводжувалася зниженим інтересом до вивчення когезії й когерентності як власне текстових категорій.

Ю. Крістєва розширила поняття діалогічності, розроблене М. М. Бахтіним. Учена вважає, що закономірно розглядати текст як історикокультурну парадигму певного суспільства. Нове поняття тексту дослідниця називає «транссеміотичним універсумом», що містить усі смислові системи і культурні коди, як у синхронічному, так і діахронічному аспектах [цит за 9, с. 181]. Можна стверджувати, що під цим кутом зору будь-який текст виступає інтертекстом, а передтекстом кожного окремого твору є не лише сукупність усіх попередніх текстів, але й сукупність спільних кодів і смислових систем, що лежать у їхній основі. Між новим створюваним текстом і попереднім «чужим» існує спільний інтертекстуальний простір, який вбирає увесь культурно-історичний досвід особистості.

Основна ідея Ю. Крістєвой зводиться до того, що текст у процесі інтертекстуалізації сам постійно трансформується, створює і переосмислює. Тому цей процес $є$ запорукою відкритості тексту.

Відкритість тексту визначається відкритістю дискурсу: існує комунікативний, когнітивний, семантичний простір («рамка»), що співвідносить текст, по-перше, з певною ментальною сферою / знаннями; подруге, 3 моделями (зразками $\mathrm{i}$ прототипами) текстотворення $\mathrm{i}$ текстосприйняття; i нарешті, 3 іншими текстами, змістовно-тематично узагальненими спільною темою [9, с. 182].

Теорія інтертекстуальності розробляється 3 урахуванням як основних властивостей тексту, так і аспектів значення тексту, відповідно йдеться про статичні й динамічні аспекти інтертекстуальності. Момент включення інших текстів або фрагментів вважається основним способом прояву категорії інтертекстуальності.

Широке дослідження інтертекстуальності розповсюджується на міжтекстові зв'язки, в яких відображається діалогічність культури або культур. На думку сучасних дослідників, крім повторюваних композиційних 
схем (наприклад, модель великої жанрової форми передбачає поділ на глави, підглави й абзаци), до проявів інтертекстуальності належить вплив творчості одних письменників на творчість інших. Повторювані мотиви можна в надлишку спостерігати у фольклорі.

Говорячи про культурну складову інтертекстуальності, варто зазначити, що на рівні композиції спостерігається «універсальний семіотичний закон», «спільний механізм текстоутворення». Інтертекстуальність співвідноситься дослідниками з пам'яттю культури, яка за Ю. М. Лотманом осмислюється як складний ієрархічно організований текст. Отже, завдяки здатності накопичувати семіотичний досвід «сукупність раніше створених вербальних і невербальних текстів (текстового простору)» вважається вченим «джерелом текстоутворення». Саме цей факт визначає закономірним трактування інтертекстуальності як складного феномену в багатовимірному культурному контексті.

Інтертекстуальність тісно пов'язана 3 поняттям «прецедентний текст». На думку Ю. М. Караулова, прецедентні тексти $є$ «хрестоматійними» текстами, які «добре відомі мовній особистості й мають вагоме значення для неї у пізнавальному та емоційному планах». Прикладами таких текстів $\epsilon$ міфи, перекази, фольклорні й біблійні тексти, а також художні й публіцистичні тексти історико-філософського i політичного характеру. Оскільки вони мають надособистісний характер, прецедентні тексти часто відносять до поняття «прецедентний феномен».

В рамках концепції В. В. Красних системоутворюючі прецедентні феномени «зумовлюють національну маркованість комунікації» i охоплюють, крім продуктів мовленнєво-розумової діяльності (вербальних і вербалізуючих феноменів), витвори живопису, скульптури, архітектури, музики, тобто можуть бути невербальними.

До вербальних прецедентних феноменів відносять прецедентне ім'я і прецедентне висловлювання. Прецедентне ім'я трактують як індивідуальне ім'я, пов'язане 3 прецедентним текстом або ситуацією, тоді як прецедентне висловлювання - закінчена і самодостатня одиниця, багаторазово вживана у мовленні, наприклад, відома цитата [8].

Під прецедентними текстами розуміють «закінчені й самодостатні продукти мовленнєво-розумової діяльності», що вербалізують, а не вербальні феномени. Таке трактування грунтується на тому факті, що прецедентні феномени зберігаються у нашій пам'яті не словесно, а у формі концептів, максимально ущільнених уявлень про сюжет, персонажі, основні події.

До вербалізуючих прецедентних феноменів учені відносять i прецедентну ситуацію, під якою розуміють «еталонну ситуацію, що відбулася у реальному чи уявному світі» [8]. Прецедентні тексти і прецедентні феномени вивчаються з позиції формування ними концептів у картині світу. 
Сучасні підходи до прецедентних феноменів і прецедентних текстів підтверджують, що при характеристиці контексту семантичні, стилістичні й естетичні текстові зв'язки, як обмежені рамками тексту, так і поза ними, описуються «з позиції їх осмислення свідомістю». Відповідно, ідея інтертекстуальності органічно вписується у концепцію розширення меж знань, пов'язаної із зростанням ролі фактору людини.

Лінгвістичне тлумачення інтертекстуальності зводиться до ії розуміння як до випадку, коли автор «навмисно тематизує» взаємодію між текстами, робить її видимою для читача за допомогою особливих формальних засобів [9, с. 187]. Така навмисно маркована інтертекстуальність передбачає, що не тільки автор навмисно і свідомо залучає у свій текст фрагменти інших перед текстів, але й адресат здатен правильно визначити авторський намір i сприймає текст в його діалогічному співвідношенню. Тут йдеться про такий комунікативний процес, необхідною умовою якого $\epsilon$ «інтертекстульне усвідомлення» обох партнерів [9, с. 187]. Таке явище С. Хольтіус називає «інтертекстуальною диспозицією», що передбачає наявність у тексті певних інтертекстуальних сигналів або індикаторів, здатних мотивувати реципієнта до пошуку зв'язку тексту з іншими текстами [цит. за 9, с. 187].

С. Загер виокремлює 3 форми інтертекстуальності:

1) абстрактно потенціально можливу інтертекстуальність;

2) актуальну, когнітивну інтертекстуальність;

3) текстуально виражену інтертекстуальність.

Перша форма характеризує «широкі культурно семіотичні відношення у текстовому універсумі», що називається «радикальною інтертекстуальністю» [9, с. 188]. Когнітивна інтертекстуальність передбачає відношення між текстом i його реципієнтом, які виникають у процесі декодування та інтерпретації. I третя з цих форм означає «вираження у канві тексту діалогу різними засобами».

Підсумовуючи сказане, слід зауважити, що термін інтертекстуальність $\epsilon$ одним 3 ключових у науці про мову, а сам феномен, що описується інтертекстуальністю, входить до переліку фундаментальних, основоположних для розвитку літературознавства та лінгвістики.

Літературна казка, яка виникла на основі народної казки, не вміщується у рамки епічного фольклорного жанру, який характеризується стійкою структурою (типові початкові й фінальні формули, персонажі, прийоми оповіді) й певними типами змісту (чарівні, побутові, авантюрні тощо). Створюючи казку, письменник вільний у виборі елементів і моделює світ, в якому гармонійно переплітаються безліч світів. Таким чином літературна казка синтезує компоненти інших епічних жанрів - роману, повісті, новели, перетворюючись в універсальний жанр, і виходить за межі своєї національної казки, звертаючись до казково-міфологічного багатства народів світу, переосмислюючи й переакцентовуючи його. 
Для жанру літературної казки принципово важливим є умова ведення живого діалогу з адресатом, що пов'язано з початковим уявленням про казку як про усний твір розважального характеру. Втім літературна казка, будучи продуктом письмового дискурсу, використовує різноманітні прийоми для ведення бесіди з читачем. На нашу думку, ці прийоми об'єднані однією спільною властивістю, а саме - інтертекстуальністю. Експлікація акту оповіді, що виражена в тексті, $є$ імітацією усного мовлення, зокрема звернення до читача. Для того щоб діалог був ефективним необхідно апелювати до спільного фонду знань, так званому інформаційному тезаурусу, що містить факти про навколишній світ, науки, культури та літератури. Упізнавані елементи у тексті казки активують увагу читача, змушують його вести діалог з автором.

Висновки i перспективи дослідження. У ході проведеного дослідження ми дійшли до висновку, що інтертекстуальність передбачає певну авторську стратегію побудови тексту на основі інших текстів, жанрів чи дискурсів, а також спосіб інтерпретації тексту, ефективність якого залежить від загальнокультурного тезаурусу реципієнта. Інтертекстуальні зв'язки в англійській літературній казці містять різні джерела та охоплюють різні системи (текст, жанр, дискурс), взаємодія між якими спостерігається на всіх рівнях текстової структури (сюжет, композиція, стиль). Перспективним уважаємо з'ясування інтердискурсивних зв'язків у тексті літературної казки 3 метою розкриття нових форм діалогу 3 читачем на основі спільного соціокультурного знання.

\section{ЛІТЕРАТУРА}

1. Арнольд И. В. Проблемы диалогизма, интертекстуальности и герменевтики. СПб.: Образование, 1995. $59 \mathrm{c} /$

2. Бахтин М. М. Эстетика словесного творчества. 2-е изд. М.: Искусство, 1986. $444 \mathrm{cl}$

3. Гадамер Г. Г. Актуальность прекрасного. М.: Искусство, 1991. 367 с.

4. Гальперин И. Р. Текст как объект лингвистического исследования. М.: Наука, 1981. 138 с.

5. Дейк Т. А. ван. Язык. Познание. Коммуникация: Перевод с англ.; сост. В. В. Петрова; под ред. В. И. Герасимова. М.: Прогресс, 1989. 310 с.

6. Лотман Ю. М. Семиосфера. СПб.: Искусство, 2000. 704 с.

7. НовиковХудожественный текст и его анализ. М.: УРСС, 2003. 301 с.

8. Пропп В. Я. Морфология «волшебной сказки». М.: Лабиринт, 1998. $512 \mathrm{c}$.

9. Чернявская В. Е. Лингвистика текста. М.: Либроком, 2009. 248 с.

10. Hunt P. Children's Literature. Oxford, UK; Malden, Mass, USA: Blackwell Publishers, 2001. 297 p. 